\title{
GROUND BASED AND AIRBORNE ATMOSPHERIC MEASUREMENTS NEAR BUCHAREST
}

\author{
Anca Nemuc $^{1}$ *, Andreea Boscornea ${ }^{2}$, Livio Belegante ${ }^{1}$, Jeni Vasilescu ${ }^{1}$, Sorin Vajaiac $^{2}$, Dragos Ene ${ }^{1}$, \\ Luminita Marmureanu ${ }^{1}$, Simona Andrei ${ }^{1}$ \\ ${ }^{I}$ National Institute of R\&D for Optoelectronics, Romania, *Email: anca@inoe.ro \\ ${ }^{2}$ National Institute for Aerospace Research "Elie Carafoli"
}

\begin{abstract}
This paper presents the results from a coordinated approach for atmospheric investigation, exploring synergies between different techniques. A wide range of instruments have been used during an intensive measurement period both from ground (lidar, sunphotometer, aethalometer and Aerosol Chemical Speciation Monitor) and airborne (aerodynamic particle sizer, the Picarro gas analyzer and the $\mathrm{NO}_{2}$ CAPS analyzer) in 2016 over Magurele, $6 \mathrm{~km}$ South West of Bucharest.
\end{abstract}

\section{INTRODUCTION}

Despite all the efforts made in recent years for improving the understanding of aerosol characteristics more detailed airborne and ground based observations of aerosol particles are needed, due to their high spatial and temporal variability[1]. A lot of experimental techniques are available today to perform measurements from ground, in situ, airborne or from satellites. Unfortunately, there are some problems in correlating these data and systematic validation of the measured data is necessary. Data collection and handling procedures are dramatically different in terms of measurement and response time, resolution and accuracy, derived parameters are inter-dependent. Airborne platforms enable new measurement geometries, leading for instance to a high sensitivity in the free troposphere. The fundamental challenge for satellites measuring air quality is to distinguish between pollution near the surface and pollution in the higher atmosphere. Scientific questions are still under debate about the vertical distribution of pollutants. Measurements from aircraft, in combination with ground-based measurements, offer a key perspective that makes such distinctions easier to make. In an ideal campaign the ground-based instruments offer a critical view of the same patches of air that an aircraft are monitoring from above (e.g.[2]). The Airborne ROmanian Measurements of Aerosols and Trace gases (AROMAT) campaigns were held in Romania in September 2014, August 2015 and 2016. They were supported by ESA in the framework of its Copernicus Earth observation programme, to prepare the validation programme of the future Atmospheric Sentinels.

A diversity of resources have been used during the campaign to measure air pollution in a pre-urban environment focusing both on the ground level concentrations and on the vertical homogeneity of the pollution plumes.

This paper presents measurements from the three days intensive period measurements 30.05-01.06 2016 over Magurele, $6 \mathrm{~km}$ South West of Bucharest.

\section{METHODOLOGY}

\subsection{Instruments}

During the AROMAT 2016 the following instruments were used:

- Aerosol lidar for dynamics of the atmospheric structure (including the Planetary Boundary Layer-PBL), backscatter coefficient and extinction coefficient profiles at several wavelengths[3], [4]

- Aethalometer AE33 measurements for mass concentration of Black Carbon particles at ground level [5]

- Sun photometer for Atmospheric Optical Depth(AOD) at 7 wavelengths[6] 
- Gas analyzers for $\mathrm{NOx}, \mathrm{NO}, \mathrm{NO}_{2}, \mathrm{SO}_{2}$, $\mathrm{O}_{3}, \mathrm{THC}, \mathrm{CH}_{4}$ and $\mathrm{CO}$ concentrations

- Aerosol Chemical Speciation Monitor for quantitative particle mass loading and chemical composition in real-time for non-refractory sub-micron aerosol particles measurements [7]

- Airborne Aerodynamic Particle Sizer

- Airborne Picarro gas analyzer- The Picarro gas analyzer, model G2401-mc, for simultaneous and continuous measurements of four most common greenhouse gases: water vapour, carbon monoxide, carbon dioxide and methane, based on near-infrared cavity ring down spectroscopy technology

- $\quad$ and the $\mathrm{NO}_{2}$ CAPS analyzer- The Cavity Attenuated Phase Shift (CAPS) nitrogen dioxide $\left(\mathrm{NO}_{2}\right)$ AS32M monitor from Environment S.A. for the $\mathrm{NO}_{2}$ volume mixing ratio using its broadband absorption in the blue and the CAPS principle [8]

\subsection{Meteorological context}

During 30.05 and 01.06.2016 south-eastern Europe was influenced by a cyclonic regime within the lowest part of the atmosphere, while in the upper troposphere two cyclonic areas were active both sides of Romania (west and east). The western cyclonic nucleus with its south-western circulation, has generated the advection of warm and humid air from Mediterranean Sea, while the diurnal heating added its energy to generate the afternoon instability.

\section{RESULTS}

\subsection{Ground based measurements}

The ground based measurements indicate the influence of local pollution source. The wind direction data at ground level shows SW influence, therefore the rural and local predominance.

During the first day of 2016 campaign a decrease of the Ängstrom exponent have been observed from the sun photometer measurements, highlighting an increase of the size particles in the upper layers above Magurele, most probably dust[4], but with no significant variation of the AOD. AOD daily average at $500 \mathrm{~nm}$ is 0.204 , while the Ängstrom exponent has a daily average of 1.096 .

During 30.05-02.06 the aerosol load above Magurele decreased as it is shown by the lidar measurements; the AOD maximum reached in the first day was about 0.38 at $532 \mathrm{~nm}$ while the minimum was 0.1 on the $1^{\text {st }}$ of June, in good agreement with the ones derived from sunphotometer measurements (Figure 1).

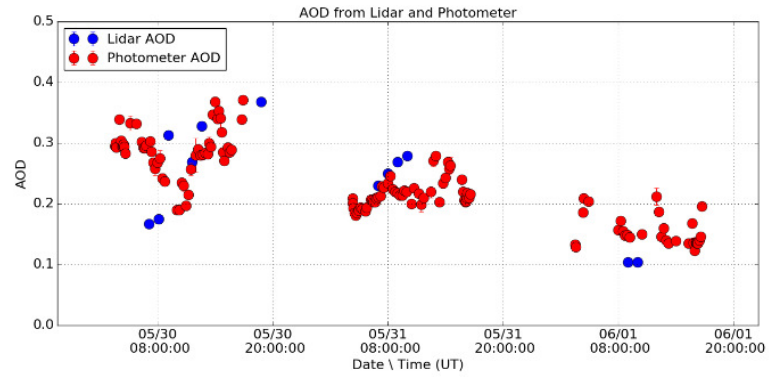

Figure 1 AOD from lidar and sun photometer during the campaign

The PBL height from lidar varied between $600 \mathrm{~m}$ to about $2000 \mathrm{~m}$. A second layer is also visible in all days. The ECMWF prognosis is completely missing the PBL height during the night (depicted as very close to zero-red in Figure 2) while during the day is between the values of the first layer detected in the lidar data and PBL height (Figure 2).

The forecast dust model (DREAM, available online at http://www.bsc.es/projects/earthscience/visor/sub fc8.php?dom $=$ med8\&type $=$ dld \&vyear $=2016 \& v$ month $=06 \&$ vday $=01 \&$ vhour $=12$ ) shows both the altitude and the amount of dust particle reaching Bucharest-Magurele area. Hysplit back trajectories show the air masses arriving at $4 \mathrm{~km}$ above the measurement site coming from North Sahara after a 48 hours travel across Mediterranean Sea and South East Europe (not shown) [9].

We can conclude that the long range transported mineral dust particles were present at $3-4 \mathrm{~km}$ altitude above Bucharest-Magurele on May 30, 2016. 


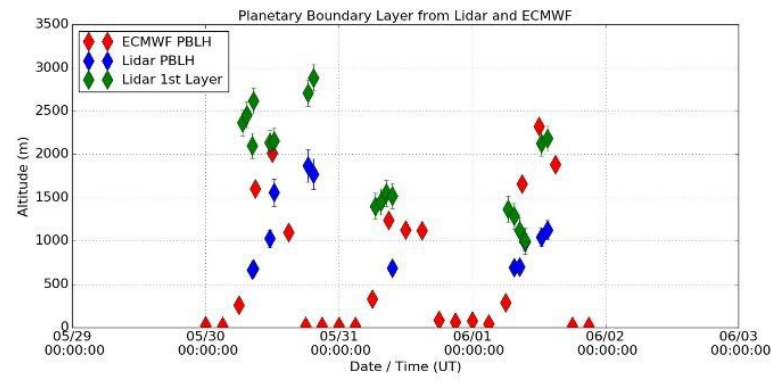

Figure 2 Planetary Boundary layer height and the first layer altitude derived from lidar measurements along with the ECMWF forecast

Similar behaviour of the concentrations for NO and $\mathrm{NO}_{2}$ with peak values at about 20ppb at the same time of the day are highlighting traffic influence.

The $\mathrm{O}_{3}$ and $\mathrm{SO}_{2}$ concentrations patterns show a diurnal cycle and maximum values during the day reaching about $90 \mathrm{ppb}$ and $3 \mathrm{ppb}$ respectively.

$\mathrm{CH}_{4}$ and $\mathrm{THC}$ concentrations at ground level were almost constant at about $2.5 \mathrm{ppm}$ with some peaks close to mid-night of about 4ppm.

High concentrations for entire period of measurements are evidenced for fossil fuel black carbon (representing approx. 83\% from total BC). Most probably source of fossil fuel BC is traffic. The average concentrations for fossil fuel are $880 \mathrm{ng} / \mathrm{m}^{3}$ since for biomass burning the average concentration is $176 \mathrm{ng} / \mathrm{m}^{3}$, normal values for this time of the year.

Low values of BC biomass burning is characteristic for the 30 May 2016, there are no sources of wood burning. Highest concentrations of $\mathrm{BC}$ fossil fuel characterize the first part of the day, almost double than the values for the evening period. The aerosol chemical composition on 30 May has been influenced only by traffic sources.

Aerosol chemical composition of particle less than $1 \mu \mathrm{m}$ depicted 5 main species: Organics, Sulphate, Nitrate, Ammonium and Chloride. Highest proportions are represented by Organics $(\sim 48 \%)$ and Sulphate $(\sim 30 \%)$. Higher concentrations at the beginning of the campaign are pin pointed, decreasing during the next days. The average concentrations are $8.11 \pm 3.48 \mu \mathrm{g} / \mathrm{m}^{3}$ on 30 May, $6.09 \pm 2.00 \mu \mathrm{g} / \mathrm{m}^{3}$ on $31^{\text {st }}$ of May and $6.11 \pm 1.65$ $\mu \mathrm{g} / \mathrm{m}^{3}$ on $1^{\text {st }}$ of June. Much lower concentration can be observed between the night of 30 May and morning of 31 May, characterized by hydrocarbon organic aerosols, coming from fresh sources local and traffic sources.

\section{$4 \quad$ Airborne in situ measurements}

A detailed flight strategy has been done before the campaign. After take-off from Strejnicu aerodrome (Prahova county), the BN2 aircraft had a North-West-South course around Bucharest Metropolitan Area, directing to the South-Western Bucharest, were the observation area was: Bragadiru and Magurele. After performing the sounding (at three different altitude levels: 300 , 500 and $1000 \mathrm{~m}$ ), the aircraft returned to Strejnicu aerodrome .The next plot (Figure 3) show the aerodynamic Particle Sizer data for the altitude levels of $341 \mathrm{~m}$. Because of the low number of data points (every minute one data point) no interpolation method could be used. Therefore, the plot contains colored points corresponding to every measured point of total aerosol concentration for the flight trajectory. The position of orange and red dots for all altitude levels correspond to identified source locations (traffic or industrial sources). It is interesting to observe that in all three altitude levels in the upper left side and in the right side of the scanned area the presence of a strong source is identified.

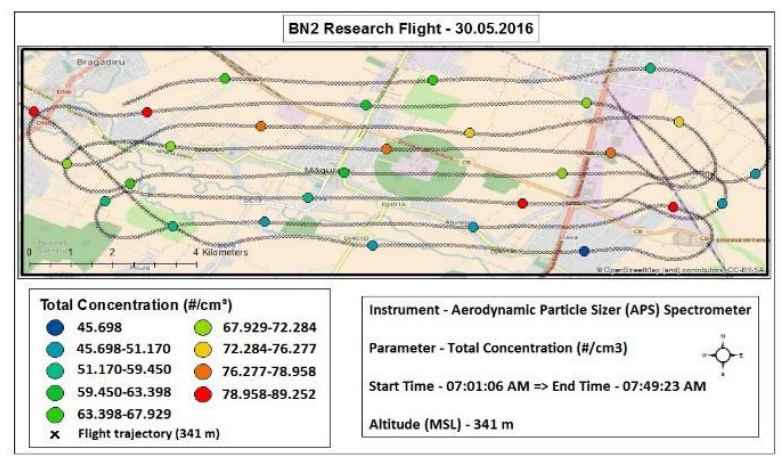

Figure 3 Aerosol total concentration recorded during flight perfomed on 30.06 .2016 at an altitude level of $341 \mathrm{~m}$

\section{CONCLUSIONS AND REMARKS}

This paper presents the measurements results from AROMAT 2016 campaign held in Romania during 30 May - 2 June. We explored the suitability of using the existing Romanian ground based and airborne instruments to assess the 
pollution sources in a region close to south west Bucharest.

Synergies between different techniques gave us useful perspective. We discovered also drawbacks to be corrected for future campaigns.

This measurement campaign carried out in early summer, has delivered these first results, showing in particular that a proportion of the pollution came from long range transported aerosols of mineral dust. Highly localized sources could be found and chemically characterized.

Supplemented with satellite observations, these campaigns could provide the missing data in an explanatory mechanism for the interaction between atmospheric chemistry, aerosols, formation and dispersal of low clouds, radiation budget and precipitation.

The goal of future campaigns could be to use these types of data to improve regional air quality models, which will support environmental policies for sustainable development of the region.

\section{ACKNOWLEDGEMENTS}

This work has been supported by the European Union's Horizon 2020 Research and Innovation Programme, under the Grant Agreement no 692014 - ECARS, by the National Core ProgramPN16.40.01.01, by ESA contract 4000113511/NL/FF/gp- AROMAT. Also this project has received funding from the European Union's Horizon 2020 research and innovation programme under grant agreement No. 654109, ACTRIS 2.

The authors gratefully acknowledge the NOAA Air Resources Laboratory (ARL) for the provision of the HYSPLIT transport model website (http://www.ready.noaa.gov) used in this publication.

\section{References}

[1] Groß, S., Esselborn, M., Abicht, F., Wirth, M., Fix, A., and Minikin, A.: Airborne high spectral resolution lidar observation of pollution aerosol during EUCAARI-LONGREX, Atmos. Chem. Phys., 13, 2435-2444, doi:10.5194/acp-132435-2013, 2013

[2] Whiteman, D. N and Coauthors: Airborne and ground-based measurements using a high- performance Raman lidar. J. Atmos. Oceanic Technol., 27, 1781-1801, doi:10.1175/ 2010JTECHA139, 2010

[3] Nemuc, A., Vasilescu, J., Talianu, C., Belegante, L., and Nicolae, D.: Assessment of aerosol's mass concentrations from measured linear particle depolarization ratio (vertically resolved) and simulations, Atmos. Meas. Tech., 6, 3243-3255, doi:10.5194/amt-6-3243-2013, 2013

[4] Nicolae, D., Nemuc, A., Müller, D., Talianu, C., Vasilescu, J., Belegante, L., \& Kolgotin, A. : Characterization of fresh and aged biomass burning events using multiwavelength Raman lidar and mass spectrometry. Journal of Geophysical Research: Atmospheres, 118(7), 2956-2965. http://doi.org/10.1002/jgrd.50324, 2013

[5] Drinovec, L., Mocnik, G., Zotter, P., Prévôt, A. S. H., Ruckstuhl, C., Coz, E., Rupakheti, M., Sciare, J., Müller, T., Wiedensohler, A., and Hansen, A. D. A.: The "dual-spot" Aethalometer: an improved measurement of aerosol black carbon with realtime loading compensation, Atmos. Meas. Tech., 8, 19651979, doi:10.5194/amt-8-1965-2015, 2015.

[6] Holben, B. N., Eck, T. F., Slutsker, I., Tanré, D., Buis, J. P., Setzer, A., Smirnov, A. (). AERONET - A Federated Instrument Network and Data Archive for Aerosol Characterization. Remote Sensing of Environment, 66(1), 1-16. http://doi.org/10.1016/S0034-4257(98)00031-5, 1998

[7] Jayne, J. T., Leard, D. C., Zhang, X., Davidovits, P., Smith, K. A., Kolb, C. E., \& Worsnop, D. R. (). Development of an Aerosol Mass Spectrometer for Size and Composition Analysis of Submicron Particles. Aerosol Science and Technology, 33(12), 49-70, 2000

[8] Kebabian, P. L., Herndon, S. C., \& Freedman, A.: Detection of nitrogen dioxide by cavity attenuated phase shift spectroscopy, Analytical Chemistry, 77(2), 724-728, 2005

[9] Stein, A.F., Draxler, R.R, Rolph, G.D., Stunder, B.J.B., Cohen, M.D., and Ngan, F., . NOAA's HYSPLIT atmospheric transport and dispersion modeling system, Bull. Amer. Meteor. Soc., 96, 2059-2077, 2015 